\title{
Frank ('Malley
}

Since its founding in 1939 the name of Frank O'Malley has graced the masthead of this journal. He played an active part in that founding, constantly at the elbow of our founding editor, Waldemar Gurian, encouraging, suggesting, rewriting, planning. Perhaps his most influential voice was felt in the determining of our policy toward a broad humanism rather than emphasize political techniques. This was characteristic of his own high idealism and his immersion in the thought of Maritain and Newman whom he elucidated so brilliantly in his courses. We deeply regret that death has now removed his name from our masthead and his influence from the Notre Dame community.

Frank O'Malley was certainly the greatest teacher of the humanities in the modern history of Notre Dame. What he did best and wanted to do most was teach. He loved his students and they returned his love with the shining radiance of their youthful idealism. As he grew older he moved more and more toward that center of his life and found less and less energy for The Review of Politics. But the present editors, also associated with The Review since its founding, are mindful of what Frank O'Malley did in our early days and join with all Notre Dame in mourning him. 